World Maritime University

The Maritime Commons: Digital Repository of the World Maritime

University

Conference Proceedings

2021

\title{
An example of risk management on board a cruise ship: COVID-19
}

Katsuya Matsui

Seafarer Group

Nobuaki Nakamura

Seafarer Group

Follow this and additional works at: https://commons.wmu.se/imla2021

Part of the Education Commons

\section{Recommended Citation}

Matsui, Katsuya \& Nakamura, Nobuaki (2021). An example of risk management on board a cruise ship: COVID-19. In Pazaver, A., Manuel, M. E., Bolmsten, J., Kitada, M., Bartuseviciene, I. (Eds.), Proceedings of the International Maritime Lecturers' Association. Seas of transition: setting a course for the future (pp. 47-52). World Maritime University. http://dx.doi.org/10.21677/imla2021.04

This Paper is brought to you courtesy of Maritime Commons. Open Access items may be downloaded for noncommercial, fair use academic purposes. No items may be hosted on another server or web site without express written permission from the World Maritime University. For more information, please contact library@wmu.se. 
http://dx.doi.org/10.21677/imla2021.04

\title{
An example of risk management on board a cruise ship - COVID-19
}

\author{
Katsuya Matsui \\ Captain of Cruise Ship, Member of Seafarer Group Hatokai, Nara, Japan , \\ ranlab@m5.kcn.ne.jp \\ Nobuaki Nakamura \\ Third Officer, Member of Seafarer Group Hatokai, Fukuoka, Japan \\ n.t.11014@gmail.com
}

\begin{abstract}
The COVID-19 outbreak in 2020 is still giving impacts to world economy and crisis management system. My cruise ship sailed from Yokohama in Jan 172020 to round Asian Cruise with 300 aged passengers and 200 crews under beginning of emergency situation.

As a reference of crisis management and human behaviour, designated in STCW convention STCW section V/2 par. 3-4 and is based on the guidelines of IMO Model Course 1.29, I introduce my experience featuring leadership of crisis management of anti-infectious disease of COVID 19 as a captain of cruise ship.

The objective of this paper is to suggest that methodology based on leader's humanism leads better or best results of risk management.
\end{abstract}

Keywords: Risk Management, Crisis Management and Human Behaviour, STCW, COVID19

\section{Introduction}

On New Year's day, I came to know about the outbreak of COVID-19 through breaking News on TV while I was enjoying my vacation at home. Because I had got a black eye on board due to SARS (Severe Acute Respiratory Syndrome) in 2002, I was very worried about this news. I felt like another serious crisis in the next couple of days was already right in front of my eyes. In this paper, I will introduce my experience of crisis management for 30 days on an Around ASIA Cruise 2020 from January to the end of February and discuss necessary leadership for crisis management on board.

\section{Sailing Away to Asia}

I was on board a Cruise Ship as a Captain and sailed away from the Port of Yokohama bound for Asian countries on $16^{\text {th }}$ January. The total number of people infected by the virus was not so serious. The World Health Organization and Japanese Government leaders also did not consider it a large threat to security at that time. However, I remember a case of Severe Acute Respiratory Syndrome in 2002 that saw most countries ban the arrival of cruise ships to prevent importing the virus and it was very hard for us just to send our 'normal' patients on board, they were all refused. In addition to that, I also had a mission to make elderly passengers, average age 70 years old, travel and go back home to Japan safely and in good health. 
Table 1. Summary of schedule of ASIA Cruise 2020

\begin{tabular}{|l|l|l|}
\hline Date & Port & Country \\
\hline $16^{\text {th }}$ Jan & Yokohama & Japan \\
\hline $17^{\text {th }}$ Jan & Kobe & Japan \\
\hline $20^{\text {th }}-21^{\text {st }}$ Jan & Keelung & Taiwan \\
\hline $24^{\text {th }}-25^{\text {th }}$ Jan & Manila & Philippine \\
\hline $29^{\text {th }}-30^{\text {th }}$ Jan & Laem Chabang & Thailand \\
\hline $1^{\text {st }}$ Feb & $\begin{array}{l}\text { Duong Don, Phu Quoc } \\
\text { Is }\end{array}$ & Vietnam \\
\hline $5^{\text {th }}-6^{\text {th }}$ Feb & Bai Chai, Halong Bay & Vietnam \\
\hline $7^{\text {th }}-8^{\text {th }}$ Feb & Da Nang & Vietnam \\
\hline $9^{\text {th }}$ Feb & Sanya & PRO.China \\
\hline $11^{\text {th }}-12^{\text {th }}$ Feb & Xiamen & PRO.China \\
\hline $16^{\text {th }}$ Feb & Kobe & Japan \\
\hline $17^{\text {th }}$ Feb & Yokohama & Japan \\
\hline
\end{tabular}

\section{Eruption of Taal Volcano in the Philippines}

While we were so busy with primary preparations for the voyage on $12^{\text {th }}$ January, I received further breaking news of the eruption of Taal Volcano in the Philippines. Some cities in the vicinity of the volcano were locked down and the local residents were warned to evacuate the area including our crew living there.

'Beginning of outbreak of virus in China' and 'Eruption of Volcano in Philippines" My sense of crisis reacted sensitively to these two Keywords and I started investigating the situation and collecting information about the crises immediately.

First at this point, I established a defined goal of 'Bring back all passengers to Japan in good health' and went into action.

\section{Leadership for Risk Management Factor-1}

\section{Gathering specific information with rapidity}

Directions of swift, specific and sufficient investigation made subordinates analyse the situation by themselves. The action can also make them recognize that this challenge is not resourceless and not thoughtless.

\section{Setting clear goals immediately}

'Bring back all passenger to Japan in good health'

\section{Expression of firm belief based on the clear goal}

Each behaviour of a leader influences the feelings of people around the leader under emergency situations. A Captain is not a medical professional; however. It's most important for a leader, not to discuss whether the goal may be right or wrong, but to set clear goals quickly in this first phase. It is also important to make judgements and decisions based on the goal. When a leader should direct concrete action, I intend that the leader must maintain fairness, not be machinelike, 
rooted with humanism because the parties who are directed to implement action also feel vigorous anxiety under crisis.

\section{Implementation of concrete measures - First Action}

As a result of the investigation, I implemented the following concrete measures on my own responsibility.

- Additional pre-purchasing of medical surgical masks to get ready for an outbreak (we were able to obtain enough stock of masks in advance because COVID-19 was not a big problem all over the world - except China - in this first phase).

In face, the purchasing manager had already ordered enough surgical masks and other necessary sanitary items before being instructed to do so, based on the experience of SARS. A leader's serious stance of fulfilling their responsibility could bring detailed plans with general cooperation. If we had started the action to secure masks and sanitary items after a week, we would only be able to get a few items.

- Going into force of measures according to the H1N1 novel influenza manual. (Company still had not established a manual of novel coronavirus.)

- Under the ship doctor's supervision, I edited a video of countermeasures and knowledge of novel coronavirus immediately and broadcasted on crew TV channels repeatedly.

\section{Leadership for Risk Management Factor-2}

What does it mean to 'take responsibility'?

A leader must always have a good reason for every move they make. This policy does not mean that a leader must resign for responsibility due to failure but that the leader expresses responsibility by implementation of concrete measures of 'I did this'; for example, to proclaim waiting and standing with an air of composure for a good chance if the general situation is bad.

\section{Implementation of concrete measures - Adaptation to changeable situation}

While the total number of patients in the city of Wuhan, People's Republic Of China, was increasing day by day, the ship arrived at Keelung, Taiwan on $20^{\text {th }}$ January. Many citizens seemed to be using medical masks in the city. Passengers' anxiety on board was growing bigger and bigger as well, because we were scheduled to visit some ports of PROC. The government of Taiwan had already started limiting entrance into Taiwan from PROC.

Considering the details of the situation and information, I called all the managers on board for a meeting to summarize their opinions. I started the following concrete measures.

- Giving up visiting ports of PROC and changing to Port of Taiwan

- Booking berths in 3 ports of Taiwan instead of in PROC

- Stopping and changing the flight schedules of further crew and passengers who have scheduled flights from PROC or via PROC

- Starting examination of other Asian ports where we will visit during the period of the Lunar New Year Festival.

- Investigating the damage situation in Manila and other provinces affected by volcanic ash, including effects on the respiratory system.

- Monitoring crew's anxiety about the virus outbreak

Healthy exchanges of ideas were generated in all departments on board and the following suggestions were proposed and carried out: 
A) Preparing charge free masks at the gangway and encouraging use of masks (we had a stock of more than 20000 masks in the store)

B) Manning an exclusive crew to enforce disinfection of all passengers' hands with alcohol disinfectant solution at all entrance of gangway, dining rooms and event spaces

C) Raising onboard level of overall sanitation and disinfection from level 1 to 2 as defined by the in-house novel influenza manual

D) Posting on bulletin board in the crew mess room regarding the world situation of COVID-19 and giving notice to crew to prevent infection. Preparing alcohol disinfection solution as well.

E) Issuing announcement of directions about COVID-19 from the ship doctor to crew and passengers through several orientation and onboard TV programs

F) Enforcing all cabin crew and gangway security staff to use surgical masks

G) Setting one isolated crew section of the cabin and passage as a Quarantine Section. The ship doctor could isolate patients showing symptoms of contagious disease in the section for a certain period even if the result of influenza examination was negative.

$\mathrm{H})$ Purchasing additional hypochlorous acid air cleaners for quarantine cabins (This item was also sold-out after one week)

I) Arranging a shuttle bus to the nearest shopping mall, where only local people go shopping, at Laem Chabang, Thailand on $29^{\text {th }}$ Jan, peak period during Lunar New Year Festival, and otherwise prohibited going ashore.

\section{Leadership for Risk Management Factor-3}

It is necessary for a leader to generate one-team solidarity by making time for attentive dialogue in order to make the team clearly understand the goal and idea. The leader needs to listen to team members while showing mutual respect and equality under clear goals and ideas. Additionally, the leader also tries to discover each member's individual talent by understanding their circumstances and position, and to assign roles to fields in which each member can demonstrate their ability with assurance.

\section{Implementation of concrete measurements - Relieving stress}

Almost no passenger and crew complained about the announcement of an alternative itinerary to Taiwan. The days had been long and threatening with further limitations to going ashore. Everybody could understand the situation but many managers reported the crew's demoralization. The ship was intended to visit the World Natural Heritage Halong Bay, Vietnam on $5^{\text {th }} \mathrm{Feb}$; however, the crew was still worried about safe shore leave for taking a breather. I discussed with the company and arranged an exclusive recommended boat cruise tour for the crew. I had already negotiated with the company to cover $50 \%$ of the cost, so most of the crew were able to gladly join this tour by adjusting their working shifts with each other. This solution enabled reducing the crew's contact with an unspecified number of people and ease their stress.

\section{Leadership for Risk Management Factor-4}

A leader needs to prepare cheerful choices, relaxation and humour full of humanity and benevolence for those who are brooding and for those who cannot break the deadlock. The humour should not overbear them but be conscientiousness. In this case, the humour could give them a mission to protect the safety of passengers.

\section{Implementation of concrete measurements - decision at turning point}


The ship arrived at Da Nang,Vietnam on $9^{\text {th }}$ Feb. It was past the peak period of the Lunar New Year Festival and it was reported to us that there were not so many tourists downtown. Vietnamese quarantine officers understood well regarding our solution of preventing infection and our sense of caution also eased a little.

However, the Taiwanese Government banned entrance of international cruise vessels into Taiwanese Ports at this time and 'Virus outbreaks of infection on board of a large cruise vessel' was big news in Japan. We are closely losing our destination.

- Most of the passengers were watching daily news about COVID-19 and kept feeling anxiety about further shore excursions themselves.

- Passengers thought that staying on board was most safe.

- We still did not have any suspected case of fever or other symptoms of infection.

For the above reasons, I made the decision to go back to Japan directly while maintaining the present stable and controlled on-board situation, in order to show the Japanese quarantine office and media a positive fact of being free from virus infection. We fixed the first Japanese port to Nagasaki, the only port where the local quarantine office could accept us generously.

No passenger complained about this decision with the removal of 3 destinations (continuous for more than a week with no landing) but the general mood on board was going slow and not lively in the following couple of days.

Therefore, I made another decision to change the planned route to Kobe passing the Japanese Inland Sea national park, a famous narrow passage of scenic beauty, after inward clearance at Nagasaki completely. And I agreed to make a large banner with the cooperation of the crew and passengers to encourage the $\mathrm{CM} / \mathrm{V}$ Diamond Princess in Yokohama. This idea was suggested by many of our crew members because many of the crew on board the Diamond Princess were ex-crew and friends, and passengers also felt deep sympathy for those who were suffering from the same threat.

The creation of the banner was very vibrant and lively. Many crews and passengers joined to write messages of encouragement and support on two large banners together.

The total number of crew and passengers who had ill health and symptoms was $30 \%$ less than that of past experiences of a long cruise itinerary when we arrived at Nagasaki and the medical record was also very orderly. We succeeded in getting good reliance from the Nagasaki quarantine office and free pratique was granted smoothly.

Most of the media crews waiting outside of the gangway could not catch any bad information through interviews with passengers because they were all very normal and seemed to be very calm.

\section{Leadership for Risk Management Factor-5}

A leader must focus on an idea and humour fostered from humanism and sympathy, which can ignite to remove deadlock of measurement. The full of motivation of leaders is the most important prime mover. Though analysis of the situation is important, the leader must sometimes trust subordinates and have broad-mindedness and courage to adopt their opinions thoroughly.

\section{1-1 Epilogue}

The ship entered the passage of the port of Yokohama and we could see the large hull of M/V Diamond Princess. There were few people on deck of the Diamond Princess. 
Many crew and passengers prepared the banners on deck and they held their breath. Just before passing right abeam of Diamond Princess, I blew a long whistle to attract attention. Many of the guests and crew on board the Diamond Princess came out on deck. Instantly I blew three long blasts again and people on both decks were waving at each other, with some of them shedding tears. Diamond Princess blew one long whistle as a reply.

\section{1-2 Conclusion}

7 important points of risk management in this case

1) Leader's faith, determination and defined clear goal

2) Human resource management to assign people to the right positions

3) Fairness based on humanism

4) Taking responsibility through actual behaviour; a leader must always have a good reason for every move they make.

5) Dialogue to generate solidarity to achieve the designated goal

6) Produce good ideas and humour removing deadlock fostered from humanism and sympathy

7) Full of motivation of front men and relationship of mutual trust between leader and subordinates to accept flexible ideas and suggestions.

All must be one team and create a chain reaction from the abovementioned factors. Then together they could derive positive human behaviour and hope in the future. I conclude these mixed tactics were an important substance of crisis management in this case.

\section{References}

Ikeda, D. The New Human Revolution Vol.22 Chapter High seas. (1995). Middleway press 